\title{
Proceeding
}

Supplementary Issue: Winter Conferences of Sports Science. International Conference of Engineering, Innovation Technology and Applied Science.

\section{Measuring tactical creativity with the help of divergent thought: Example of TRNC U-21 football teams}

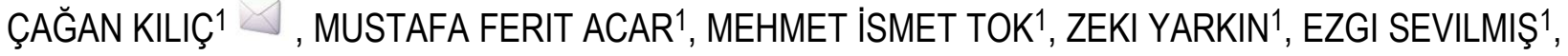 \\ NAZIM BURGUL2 \\ ${ }^{1}$ Girne American University, Cyprus \\ ${ }^{2}$ Near East University, Cyprus
}

\begin{abstract}
This study aims on the assessment of the situations of tactical orientation of 36 young, elite soccer players born in the years 1999-2000-2001, selected between 2 cities, 6 teams which belong to Cyprus Turkish Football Association (Kıbrıs Türk Futbol Federasyonu) in Turkish Republic of Northern Cyprus. This study evaluates the aspects in two ways. In order to evaluate the tactical directed situations, specific tactics and creative performance were measured with respect to Game Test. In case 1, Longitudinal design was carried to analyse intra-individual improvements of elite young football players according to football-specific creativity and tactical game intelligence by using a dynamic performance diagnostic tool. In case 2, cross-sectional design was carried in which objective, valid, differentiative enough to record, tactical indicators were created to measure football-specific creativity and game intelligence as a diagnostic instrument. In both of the studies, different evaluation criteria were spotted and with these criteria, players were scored. According to these scores, divergent tactical thinking results has been obtained. The results according to divergent tactical thinking showed that disparate changes were obtained in between the players of KTFF U-21. As a result, the practical implications for the processes of training has been deeply discussed in both cases.

Keywords: Tactical creativity; Tactical thinking; Convergent thought; Divergent thought; Game-test situation.
\end{abstract}

\section{Cite this article as:}

Kiliç, Ç., Acar, M.F., Tok, M.I., Yarkin, Z., Sevilmiş, E., \& Burgul, N. (2020). Measuring tactical creativity with the help of divergent thought: Example of TRNCU-21 football teams. Journal of Human Sport and Exercise, 15(2proc), S408-S416. doi:https://doi.org/10.14198/ihse.2020.15.Proc2.31

Corresponding author. Girne American University, Cyprus.

E-mail: cagankilic.df@gmail.com

Supplementary Issue: Winter Conferences of Sports Science. International Conference of Engineering, Innovation Technology and Applied Science.

JOURNAL OF HUMAN SPORT \& EXERCISE ISSN 1988-5202

(c) Faculty of Education. University of Alicante

doi:10.14198/jhse.2020.15.Proc2.31

S408 | 2020| Proc2 | VOLUME 15

(C) 2020 University of Alicante 


\section{INTRODUCTION}

Today, creativity is the basis of technological developments in every field. Civilizations owe developments to the efforts of creative individuals. Creativity takes many forms, from ordinary products to magnificent designs, from the simplest crafts to the ultimate art, and nobody will describe it exactly the same way. There is always something to praise. However, creativity is about much more than passive appreciation (Cox D. 2013).

Creativity is the sensation of problems or gaps in knowledge, creation of thoughts or hypotheses, testing, development and transmission of data (Torrence E.P., 1995).

Creativity, which is more important in sports branches, where artistic expressions contribute more in sports, reveals itself in magnificent dimensions especially in sports branches where the number of spectators is high.

According to Csikszentmihalyi, creativity is defined as being both the one way and versatile thinking ability (Csikszentmihaly, 1996). As in every field, creativity has gained more importance in the field of sports. An important part of creativity education in football appears as tactical creativity.

In developing tactical creativity, the focus should be on developing habits of thinking different forms of solution (divergent thought) that may come to mind rather than the simple solution (convergent thought) that comes to mind to develop solutions that are different from the expectations of competitors. According to Memmert which was identified in Sports and Creativity, the concept of divergent thinking skills equivalent to tactical creativity (Memmert, 2011). In parallel, Scibinetti et.al (2011) asserts that creative behaviour plays a key role in the performance of many sports. When considering the diverging psychomotor and cognitive demands that characterize different sports, however, one can assume that creativity is highly task-specific within this domain. For coaches it is necessary to constantly strengthen athletes' self-efficacy and provide them with the space for the development of creativity and technological capacity in order to specifically improve their athletic performance. (Wu, et.al.,2012).

Nowadays, the issue of creativity in football field has started to be examined with its important dimensions. For this purpose, many researchers, especially Daniel Mammert from Cologne Sports High School in Germany, started to work in this field. Nowadays, there are many obstacles that restrain the creative potential, such as the lack of street sport, unadjusted training, mechanization of play, decrease of the game enjoyment and a narrow game knowledge. Moreover, the current sport systems are not aligned in order to supply these necessities. In fact, a rigid linear environment prevails and players are constantly overwhelmed by a lack of adaptability during the game. (Santos,et.al,2016) We have embarked on the research of the TRNC leagues for these different events, which have had a very good effect on the audience. As our research progresses, it can be said that the necessity of giving importance to creativity education in all teaching stages, especially in the lower age categories, has emerged more.

\section{MATERIAL AND METHOD}

In this research, an example of the "GAME-TEST form used to detect divergent thoughts" developed by Daniel Memmert from Cologne Sport Hochschule (Memmert D.2010).

This Game-test application consists of three clubs participating in the competitions in the TRNC U-21 Leagues from Lefkoşa, one of the two major districts of the TRNC. Yenicami Ağdelen Spor Kulübü, Çetinkaya Türk Spor Kulübü, Küçük Kaymaklı Spor Kulübü and three other clubs from other county Girne; It was held 
on 36 young football players between the ages of 19-21 from the Türk Ocağı Limassol Spor Kulübü, Merit Alsancak Spor Kulübü and Girne Halkevi Spor Kulübü. It is thought that such a research is an original research since it has never been done in TRNC before.

All creativity game tests developed by Memmert (2006b; 2007; 2010a), validity and reliability were applied to all players.

\section{Test: (Evaluate open opportunities)}

It is an area with $8 \times 7 \mathrm{~m}$ dimensions and a $1.5 \mathrm{~m}$ high net in the middle of the field. Actions are recorded with a camera up to $8 \mathrm{~m}$ from this net. There is also a camera placed at the opposite angle. $1 \mathrm{~m}$ below the net there are 3 defenders in a wide area. There is a 4 people offensive team with 2 players on each side of the net.

Only the technical activities of the convergent and divergent creative thinking of the attacking players are evaluated. Attackers try to pass the ball to the teammates in the opponent's field through the gaps of the defenders only after their passing between them without dribbling. Only creative techniques are evaluated.

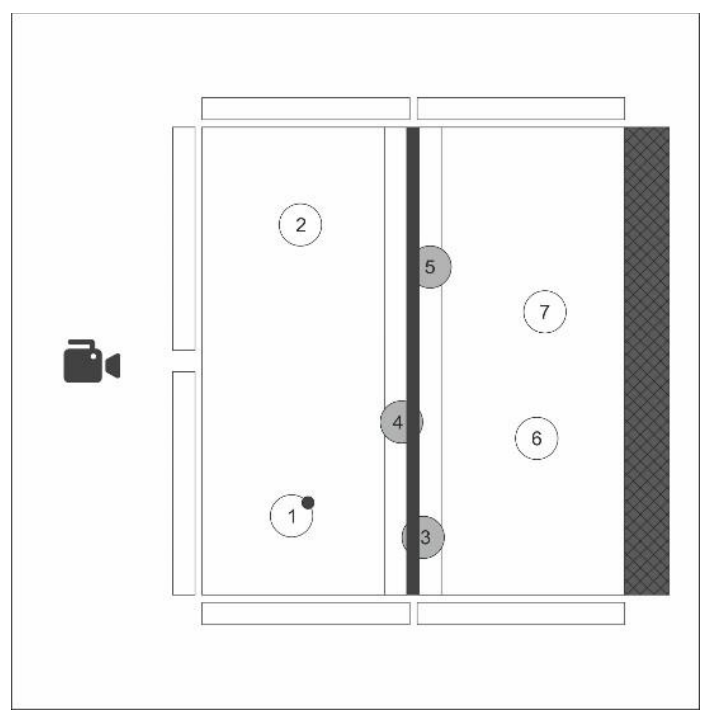

Convergent and Divergent creative actions were determined by the commission of experts consisting of 3 people (both university lecturers and UEFA Pro and UEFA A licenses).

The criteria were determined as follows:

Convergent tactical thinking activities:

- Accurate pass at the right time,

- Accurate pass to the right place,

- Use of wall pass,

- Non-dominant footed accurate pass,

- A pass with using different parts of the body or foot.

Divergent Tactical Thinking Activities:

- An accurate pass to hit the ball with a curved stroke, 
- Correct pass with no-look hit,

- An accurate pass with heel hit pass,

- An accurate pass from hitting between the legs,

- Accurate pass after different foot-work.

Attacking Players took part in the test to play at least 2 Attackers in 5 circuits played for 3 minutes each. The images recorded after the game-test were repeatedly watched and scored by 3 experts. 1 point was given to each creative event. The maximal score obtained from all tests is 10 points.

\section{Testing (Presenting and heading)}

In a playing field of $9 \times 9 \mathrm{~m} .3$ offensive players play against 3 defenders in 4 halves of 3 minutes. Each player must be able to play as an attacker at least 2 times. Defenders are asked not to get too close to attack players. When the defenders grab the ball, the game is started from the $1 \mathrm{~m}^{2}$ area in the middle of the field. Attackers constantly pass and try to show their creativity without losing the ball to the defenders. The images obtained are evaluated by the expert committee of 3 people in terms of creativity criteria and scored as in the 1st Test.

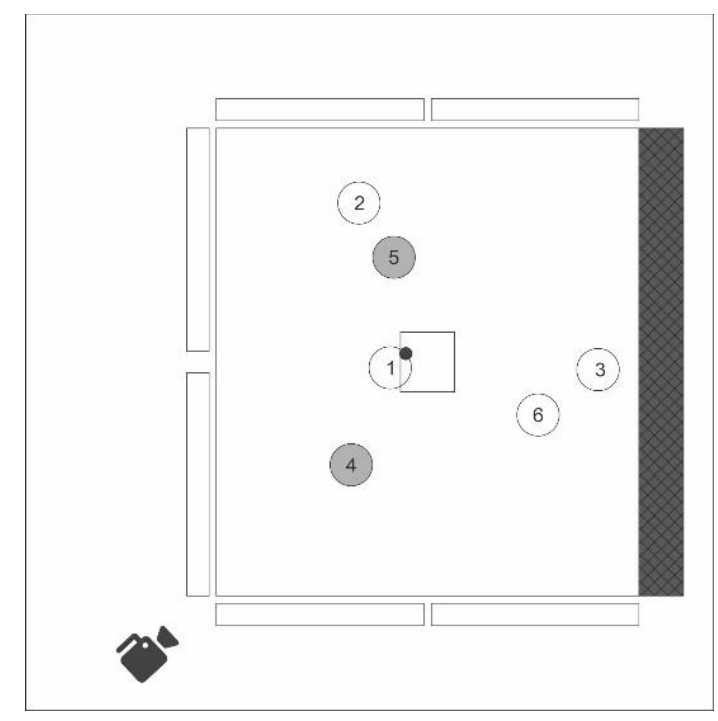

SPSS 24.0 is used to make statistical comparisons and interpretations of scores obtained from 2 different creativity tests for determining convergent and divergent creative thoughts they were processed in the packet statistics program.

\section{FINDINGS AND DISCUSSION}

\section{Statistical analysis of data}

In the study, statistical analysis of Divergent-Convergent Thought scores given to footballers by the evaluators was performed with Statistical Package for Social Sciences (SPSS) 24.0 software.

Interclass correlation (ICC) values between the scores given by the evaluators participating in the study to Divergent Thought (I-II) and Convergent Thought (I-II). 
The distribution of footballers according to some introductory characteristics was determined by frequency analysis and descriptive statistics such as mean, standard deviation, minimum and maximum value were shown for Divergent-Convergent Thought scores.

Regarding the comparison of Divergent Thought and Convergent Thought scores, first of all, the compliance of the scores with the normal distribution was examined with the Shapiro-Wilk test and it was determined that it did not show a normal distribution. For this reason, non-parametric hypothesis tests such as Wilcoxon test, Mann-Whitney $\mathrm{U}$ test, Kruskal-Wallis $\mathrm{H}$ test and Spearman test were used.

Table 1. Some introductory features of football players $(n=36)$.

\begin{tabular}{lcc}
\hline & Number $(\mathbf{n})$ & Percent (\%) \\
\hline Region & 18 & 50.00 \\
Girne (Kyrenia) & 18 & 50.00 \\
Lefkoşa (Nicosia) & 12 & \\
\hline Position & 12 & 33.33 \\
Defence & 12 & 33.33 \\
Midfield & & 33.33 \\
Striker & 12 & \\
\hline Date of Birth & 12 & 33.33 \\
1999 & 12 & 33.33 \\
2000 & & 33.33 \\
2001 & 6 & 16.67 \\
\hline Team & 6 & 16.67 \\
A.Y.S.K. & 6 & 16.67 \\
Ç.T.S.K. & 6 & 16.67 \\
G.H.E. & 6 & 16.67 \\
K.K.T.S.K. & 6 & 16.67 \\
T.O.L. & & \\
Y.A.K. & & \\
\hline
\end{tabular}

In Table 1, the findings regarding the distribution of the football players participating in the research according to some introductory characteristics are given.

When Table 1 is examined, it was determined that $50 \%$ of the football players included in the study played in Kyrenia and $50 \%$ in Nicosia region teams, $33.33 \%$ played in defence, $33.33 \%$ played in midfield and $33.33 \%$ played in forward position. It was determined that $33.33 \%$ of the football players included in the study were born in 1999, 33.33\% were 2000 and 33.33\% were 2001 births.

Table 2. Inter-rater ICC values $(n=36)$.

\begin{tabular}{lccc}
\hline & \multirow{2}{c}{ ICC } & \multicolumn{2}{c}{ 95\% G.A. } \\
& & Down & Up \\
\hline Divergent Thought (I) & $0.88^{* *}$ & 0.81 & 0.93 \\
Divergent Thought (II) & $0.83^{* *}$ & 0.73 & 0.90 \\
Convergent Thought (I) & $0.97^{* *}$ & 0.94 & 0.98 \\
Convergent Thought (II) & $0.93^{* *}$ & 0.89 & 0.96 \\
\hline
\end{tabular}

${ }^{* *} p<.01$. 


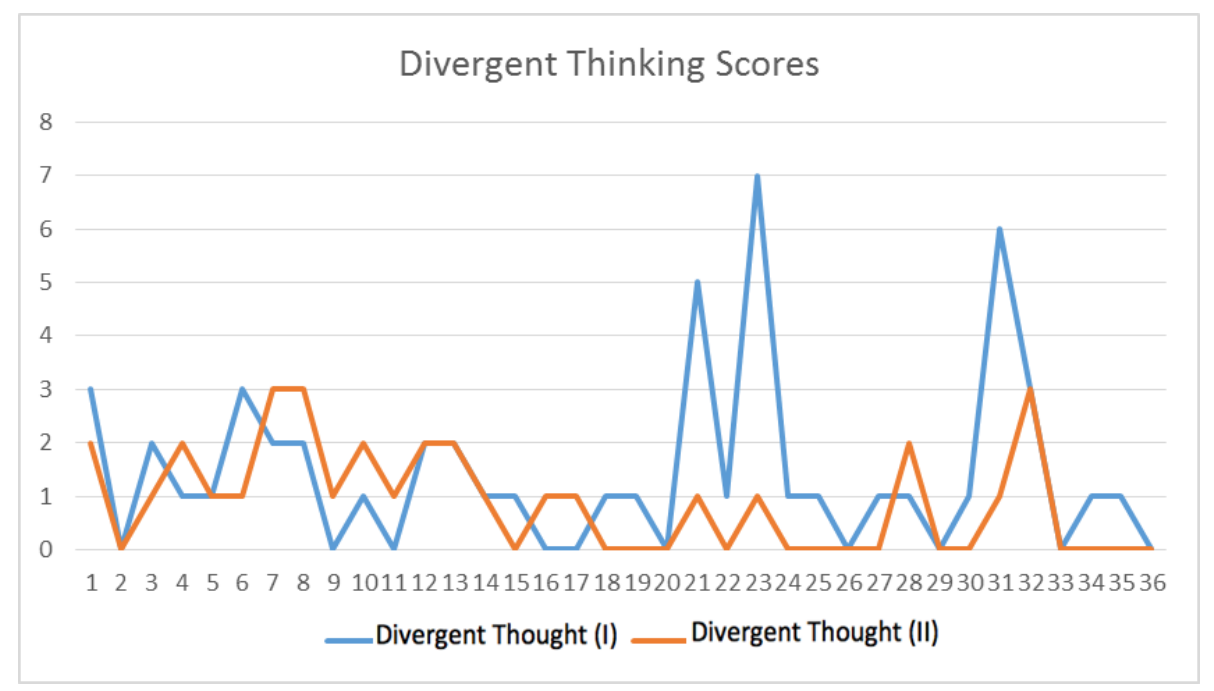

Figure 1. Divergent thinking scores of football players.

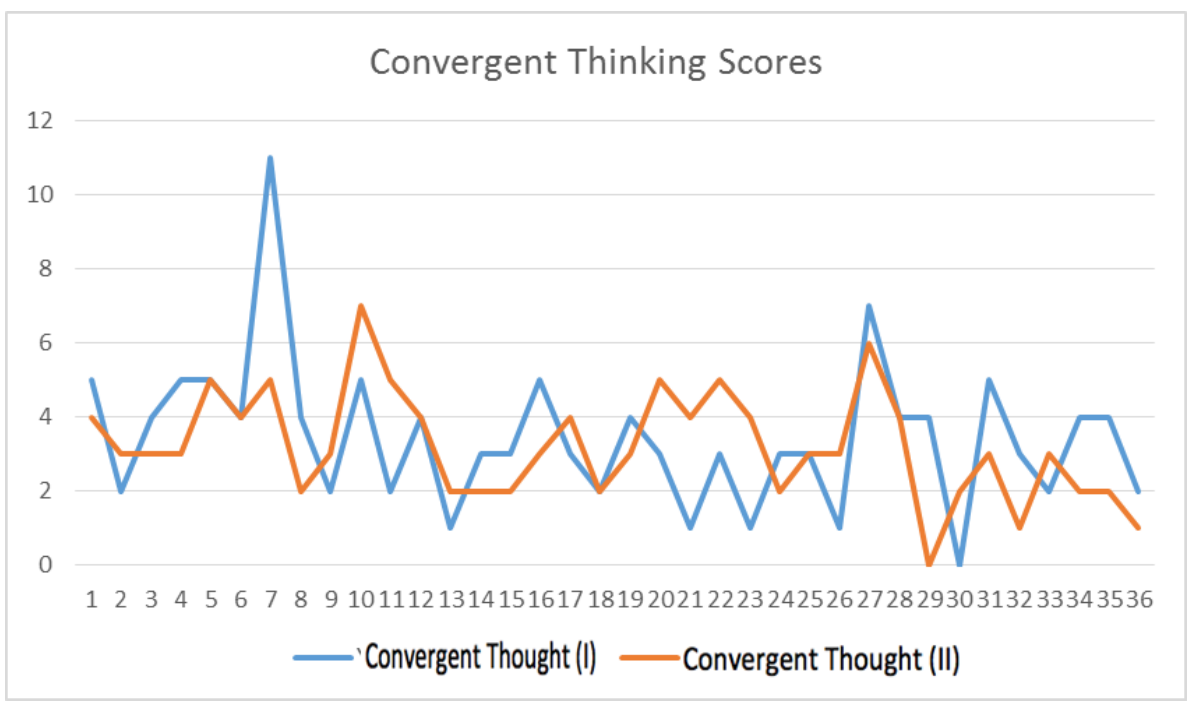

Figure 2. Convergent thinking scores of football players.

In Table 2, the correlation (ICC) values between the scores given by the evaluators participating in the research to Divergent Thought (I-II) and Convergent Thought (I-II) are shown.

When Table 2 is analysed, the ICC coefficient between 3 assessors' Divergent Thought (I) scores is 0.88 , the coefficient between Divergent Thought (II) scores is 0.83 , the coefficient between Convergent Thought (I) scores is 0.97 and the Convergent Thought (II) scores ICC coefficient was determined to be 0.93 . Fleiss (1986) stated that if the correlation coefficients were low at 0.40 , the fit was low, if it was between 0.40 and 0.75 , the fit was medium, and if it was 0.75 , the fit was high. Accordingly, it was determined that there was a high agreement between the scores of 3 evaluators to Divergent Thought (I-II) and Convergent Thought (III). 


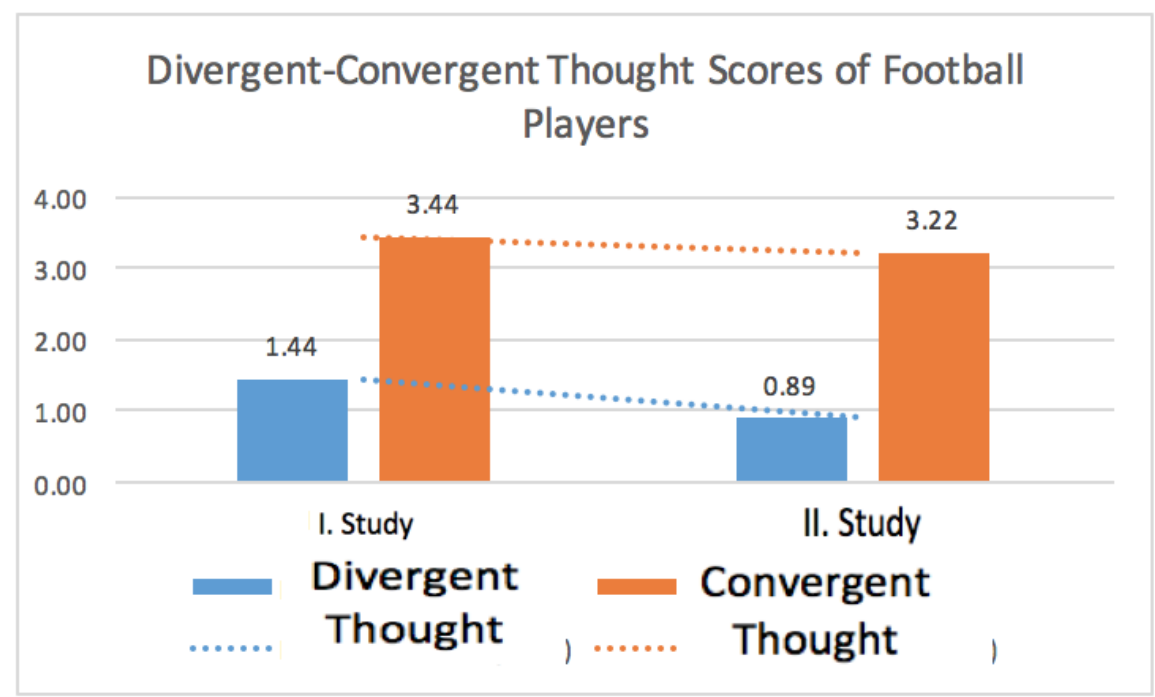

Figure 3. Divergent-Convergent thought scores of football players.

According to Figure 3, the scores of Divergent Thought I. study scores of football players included in the research $=1.44$, II. study scores were determined to $b e=0.89$. Convergent Thought $\mathrm{I}$. study scores of football players $=3.44$, while II. study scores $=3.22$ found.

Table 3. Comparison of football players' divergent thought (i-ii) and convergent thought (i-ii) scores $(n=36)$.

\begin{tabular}{lccccccc}
\hline & $\mathbf{n}$ & $\overline{\boldsymbol{x}}$ & $\mathbf{s}$ & $\mathbf{M i n}$ & $\mathbf{M a x}$ & $\mathbf{Z}$ & $\mathbf{p}$ \\
\hline Divergent thought (I) & 36 & 1.44 & 1.66 & 0 & 7 & \multirow{2}{*}{-1.842} & \multirow{2}{*}{066} \\
Divergent thought (II) & 36 & 0.89 & 0.98 & 0 & 3 & & \\
\hline Convergent thought (I) & 36 & 3.44 & 1.98 & 0 & 11 & \multirow{2}{*}{-0.398} & \multirow{2}{*}{.691} \\
Divergent thought (II) & 36 & 3.22 & 1.48 & 0 & 7 & & \\
\hline
\end{tabular}

Divergent Thought I. study and II. study scores and Convergent Thought I. study and II. study scores were compared with the Wilcoxon test and the findings are shown in Table 3.

Divergent Thought I. study and the II. there was no statistically significant difference between study scores $(p>.05)$. Although study scores for the first were higher than study scores, this difference was not statistically significant. Convergent Thought of the footballers I. study and II. there was no statistically significant difference between study scores $(p>.05)$. Accordingly, the Convergent Thought of the football players I. study and II. study scores are similar.

Table 4. Comparison of footballers' divergent-convergent thought scores $(n=36)$.

\begin{tabular}{lccccccc}
\hline & $\mathbf{n}$ & $\overline{\boldsymbol{x}}$ & $\mathbf{s}$ & $\mathbf{M i n}$ & $\mathbf{M a x}$ & $\mathbf{Z}$ & $\mathbf{p}$ \\
\hline Divergent thought $(\mathrm{I})$ & 36 & 1.44 & 1.66 & 0 & 7 & \multirow{2}{*}{-4.001} & \multirow{2}{*}{$000^{* *}$} \\
Convergent thought $(\mathrm{I})$ & 36 & 3.44 & 1.98 & 0 & 11 & & \\
\hline Divergent thought $(\mathrm{II})$ & 36 & 0.89 & 0.98 & 0 & 3 & \multirow{2}{*}{.401} & \multirow{2}{*}{$.000^{* *}$} \\
Convergent thought (II) & 36 & 3.22 & 1.48 & 0 & 7 & &
\end{tabular}


Table 4 shows the results of the Wilcoxon test regarding the comparison of Divergent Thought and Convergent Thought scores of football players. The difference between the scores of Divergent Thought I. study and Convergent Thought I. study was found to be statistically significant $(p<.01)$. Convergent Thought I. study scores of players were higher than Divergent Thought I. study points. Divergent Thought of Players II. work and Convergent Thought II. it was determined that there was a statistically significant difference between study scores and Convergent Thought I. study scores were higher than Divergent Thought I. study scores $(p<.01)$

Table 5. Correlations between footballers' divergent thought (I-II) and convergent thought (I-II) scores.

\begin{tabular}{|c|c|c|c|c|}
\hline & $\begin{array}{l}\text { Divergent } \\
\text { thought (I) }\end{array}$ & $\begin{array}{l}\text { Divergent } \\
\text { thought (II) }\end{array}$ & $\begin{array}{l}\text { Convergent } \\
\text { thought(I) }\end{array}$ & $\begin{array}{l}\text { Convergent } \\
\text { thought (II) }\end{array}$ \\
\hline \multicolumn{5}{|c|}{ Divergent thought $r 1$} \\
\hline & $p$ & & & \\
\hline Divergent thought & r .522 & 1 & & \\
\hline (II) & $p .001^{* *}$ & 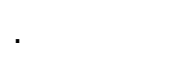 & & \\
\hline Convergent & r .214 & .341 & 1 & \\
\hline thought (I) & p. .211 & $.042^{*}$ & . & \\
\hline Convergent & r .073 & .241 & .308 & 1 \\
\hline thought (II) & p. .671 & .157 & .068 & \\
\hline
\end{tabular}

Spearman test results for the correlations between the Divergent Thought (I-II) and Convergent Thought (III) scores of the football players included in the research are given in Table 5.

Divergent Thought I. study scores of football players participating in the study and Divergent Thought II. There was a statistically significant correlation between study scores $(p<.05)$. This correlation is a positive and strong correlation. Accordingly, as the scores of the players Divergent Thought I. increased, Divergent Thought II. study scores also increase.

Convergent Thought I. Study Scores of Football Players and Close Thought II. There was no statistically significant correlation between study scores $(p>.05)$.

It was observed that there was no statistically significant correlation between Convergent Thought I. study scores of the players participating in the study and Divergent Thought I. study scores $(p>.05)$.

Convergent Thought I. study scores of footballers and Divergent Thought II. there was a statistically significant correlation between study scores $(p<.05)$.

This correlation is positive and medium strength. Accordingly, as the football players' Convergent Thought I. study scores increase, Divergent Thought II. study scores also increase. Convergent Thought of the football players participating in the research II. Divergent Thought I. study scores and Divergent Thought II. There were no statistically significant correlations between study scores $(p>.05)$.

\section{CONCLUSION}

Within both studies in this research, differences have not been identified in the representation of neither Convergent Tactical Thinking nor Divergent Tactical Thinking. So, the scores that are achieved at the end of Test 1 are not differentiated in terms of both features. 
Another outcome that is observed from this research is that, it is an expected outcome for the scores of Divergent Tactical Thinking, which is more valuable in terms of creativity, to be lower than the scores of Convergent Tactical Thinking.

As Rezulli defined in 1977, one of the 3 main components of talent is to show superior creativity level and to provide an approach for solutions of problems with a Divergent Tactical Thinking dimension (Bildiren, 2007). Lastly, it is established that, in statistical terms there is a significant correlation between the scores of Study I. Convergent Tactical Thinking and the scores of Study II. Divergent Tactical Thinking of football players. With this outcome, Divergent and Convergent Tactical Thinking within creative thinking, creates a resource for future research regarding the determination of talent.

\section{REFERENCES}

Bildiren A. (2007). Üstün Yetenekli Öğrencilerin Belirlenmesine Yönelik Bir Tanılama Yönteminin Kullanılabilirliğinin İncelenmesi. Pamukkale Üniversitesi Eğitim Fakültesi Dergisi 2007 vol. 22.(2). https://doi.org/10.17152/gefad.332459

Cox D. (2018). Yaratıcı Düşünme, (çev. Ün E.),Nobel Yaşam Yayınları.

Csikszentmihalyi, M . (1996)."The creative Personality." Psychology Today, 29(4), 36-40.

Memmert D \& Perl J. (2009) Game Creativity analysis using neural networks, Journal of Sports Sciences, 27(2) 139-149. https://doi.org/10.1080/02640410802442007

Memmert D. (2010). Testing of Tactical Performance in Youth Elite Soccer, Journal of Sports Science and Medicine, 9 .

Memmert D. (2011) Sports and Creativity, Encyclopedia of Creativity, Second Edition, vol. 2, pp. 373378 San Diego: Academic Press. https://doi.org/10.1016/b978-0-12-375038-9.00207-7

Santos, S. D., Memmert, D., Sampaio, J., \& Leite, N. (2016). The spawns of creative behavior in team sports: A creativity developmental framework. Frontiers in psychology, 7, 1282. https://doi.org/10.3389/fpsyg.2016.01282

Santos S., Jimenez S.,Sampaio J.,Leite N. (2017) Effects of the Skills4Genius Sports-based Training Program in Creative Behavior, Journal PLOS I one, 23. https://doi.org/10.1371/journal.pone.0172520

Scibinetti, P., Tocci, N., \& Pesce, C. (2011). Motor creativity and creative thinking in children: The diverging role of inhibition. Creativity Research Journal, 23(3), 262-272. https://doi.org/10.1080/10400419.2011.595993

Torrence, E. P. (1995). Why fly. A philosophy of creativity. Norwood, NJ.

Wu, C. S., Lee, C. J., \& Tsai, L. F. (2012). Influence of creativity and knowledge sharing on performance. Journal of Technology Management in China.

\section{(9) $\odot \Theta \Theta$}

This work is licensed under a Attribution-NonCommercial-NoDerivatives 4.0 International (CC BY-NC-ND 4.0). 